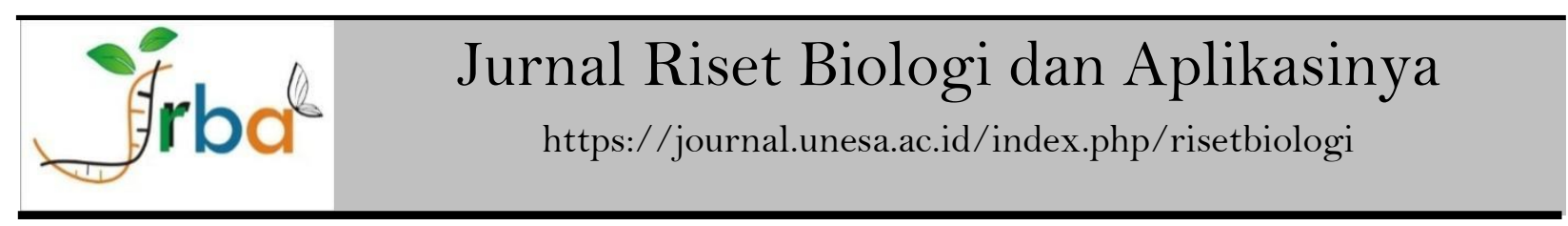

\title{
Difference of Red Blood Cell Count (RBC) Levels in Diabetes Mellitus Type II with Ulcers and without Ulcers
}

\author{
Perbedaan Jumlah Sel Darah Merah (RBC) pada Diabetes Mellitus Tipe II \\ dengan Ulkus dan tanpa Ulkus
}

Miftahul Mushlih

Fakultas Ilmu Kesehatan, Universitas Muhamadiyah Sidoarjo

\section{Article History \\ Received : 29 November 2019 Approved : 6 Februari 2020 Published : 31 Maret 2020 \\ Keywords: ulcers, without ulcers, diabetes mellitus, RBC, HGB}

Kata Kunci: ulkus, tanpa ulkus, diabetes mellitus, $R B C, H G B$

\begin{abstract}
Type II diabetes mellitus (T2DM) is a metabolic disorder that has potential causing ulcer complications. Ulcers occur due to peripheral vascular abnormalities and trauma. The occurrence of ulcers allows differences in the hematology characteristics in sufferers. This study aimed to determine the comparison of the blood picture between T2DM with ulcers and T2DM without ulcers. This was an analytical descriptive research using 29 samples (10 T2DM samples with ulcers and 19 T2DM samples without ulcers). A complete blood test was performed using Sysmex Kx-21N hematology analyzer. Data were analyzed using Independent T-test and Mann-Whitney $\mathrm{U}$ depends on the normality. Normality was done using Shapiro Wilk (Confident Level: 95\%). The results of this study indicated that Red blood cell count (RBC) and Hemoglobin Count (HGB) differ significantly between T2DM with ulcers and T2DM without ulcers (p: 0.012 and 0.006). Identification of HGB levels was highly recommended to get proper treatment in T2DM.
\end{abstract}

\section{Abstrak}

Diabetes mellitus tipe II (DMT2) merupakan kelainan metabolik yang berpotensi mengakibatkan komplikasi ulkus. Ulkus terjadi akibat adanya kelainan pembuluh darah perifer dan trauma. Kejadian ulkus menyebabkan perbedaan karakter hematologi pada penderitanya. Penelitian ini bertujuan untuk membandingkan gambaran darah antara DMT2 dengan ulkus dan DMT2 tanpa ulkus. Penelitian ini merupakan penelitian deskriptif analitik dengan menggunakan sampel sebanyak 29 (10 sampel DMT2 dengan ulkus dan 19 sampel DMT2 tanpa ulkus). Pemeriksaan darah lengkap dilakukan menggunakan Sysmex Kx-21N hematology analyzer. Analisis data dilakukan dengan Independent T test dan uji Mann-Whitney U tergantung pada normalitas data. Normalitas dianalisis menggunakan uji Shapiro Wilk (Confident Level: 95\%). Hasil Penelitian ini menunjukkan Red blood cell count (RBC) dan Hitung Hemaglobin (HGB) berbeda secara nyata antara DMT2 dengan ulkus dan DMT2 tanpa ulkus (p: 0.012 dan 0.006). Identifikasi HGB sangat direkomendasikan untuk mendapatkan pengobatan pada DMT2.

How to cite:

Muslih, M. 2020. Difference of Red Blood Cell Count (RBC) Levels in Diabetes Mellitus Type II with Ulcers and without Ulcers . Jurnal Riset Biologi dan Aplikasinya, 2(1),6-10. 


\section{INTRODUCTION}

Diabetes Mellitus is a metabolic disorder caused by unproductive, not optimal insulin performance or both (Suneja et al., 2018). Diabetes can be categorized into Type I Diabetes Mellitus (T1DM), Type 2 Diabetes Mellitus (T2DM), Gestational Diabetes Mellitus and Diabetes Mellitus which causes are unknown (Ekoe et al., 2018). Currently, T2DM abnormalities in the sixth rank cause of death in the world. In 2030 the prevalence of DM in Indonesia was predicted will increase within 366 million people. The prevalence of Diabetes Mellitus in the world tends to increase and reach $4.4 \%$ (WHO, 2004). It is caused the disorder not only comes from genetic factors but also environmental factors (Hu, 2011). Understanding of T2DM is more difficult caused it is a multi-genomics disorder (Tsaih et al., 2014).

T2DM complications cause sufferers to experience prolonged pain (Lathifah, 2017). These complications may as macrovascular and microvascular complications. Macrovascular complications include coronary artery disease, peripheral arteries, and stroke. While, microvascular complications include diabetic nephropathy, neuropathy, and retinopathy (Yuhelma et al., 2015). In the long period, T2DM sufferers can cause several problems such as decreased quality of vision, the emergence of ulcers or gangrene, kidney damage, high blood pressure, liver damage and even stroke (Tsaih et al., 2014).

An ulcer is one of the complications that are often experienced by people with T2DM. As many as $15 \%$ of T2DM sufferers have ulcers (Aumiller \& Dollahite, 2015). The dominant risk factors causing ulcers are Peripheral Artery Disease (PAD) and trauma (Loviana et al., 2015). Ulcers with extreme conditions will result in amputations to prevent wider complications (Aumiller \& Dollahite, 2015). The occurrence of ulcers can also be more dangerous if accompanied by a serious infection (Fitria et al., 2017). Early treatment of ulcers is one of the keys to avoiding broader complications (Mirtha et al., 2018). The factors that influence ulcer occurrence are the duration of DM, neuropathy, PAD, history of trauma, and foot care are risk factors for diabetic ulcers (Loviana et al., 2015). Social support is needed for DMT2 to keep trying to heal and improve the awareness of treatment (Ramkisson et al., 2017).

Hematology character influences someone with DM condition (Biadgo, 2016). Several studies have shown differences in the character of hemoglobin in people with T2DM with ulcers and without ulcers. However, information about the characteristics of hematology in patients with DM is still limited (Thomas et al., 2005). This study aimed to determine differences in the characteristics of hematology in T2DM with ulcers and without ulcers.

\section{MATERIAL AND METHODS}

This research was cross-sectional. The ethical study was approved by the ethics commission of Airlangga University, Indonesia with no. 195 / HRECC.FODM / V / 2019. A total of 29 samples were taken from various places in Sidoarjo. 10 T2DM samples were taken at Rumah Luka Sidoarjo Branch. Whereas T2DM samples without ulcers were taken from several places (health centers) in Sidoarjo. Whole Blood was taken by macro sampling in $3 \mathrm{cc}$ venous blood into an EDTA anticoagulant tube. Furthermore, T2DM blood samples were labeled and immediately stored in a cooling cupboard $4^{\circ} \mathrm{C}$. Complete blood count was conducted using hematology Analyzer Sysmex Kx$21 \mathrm{~N}$ with analyzed parameters analyzed were White blood cell count (WBC); Red blood cell count (RBC); Calculate Hemoglobin (HGB); Hematocrit (Ht or HCT); Average red blood cells (Mean Corpuscular Volume / MCV); Mean corpuscular hemoglobin or $\mathrm{MCH}$; Mean corpuscular hemoglobin concentration or MCHC; Platelet (PLT). Calculation of different tests was conducted by using independent T-test and Mann-Whitney U test depending on the normality test. Normality Test used was Shapiro-Wilk. The Confident Level used was $95 \%$.

\section{RESULT AND DISCUSSION}

Based on the research results, it was found that Diabetes Mellitus Type II was obtained; with a composition of $60 \%$ being male and $40 \%$ were female. The sample was obtained from Rumah Luka Sidoarjo. The results of this study can be described according to the observed parameters ie WBC on T2DM obtained at $7210 \pm 3839.11 / \mathrm{ul}$ (Sign. 0.327) with a lower value compared to T2DM without ulcers $8663.15 \pm 3668.81$ ul; whereas the parameters of HCT in T2 DM with ulcers have an average of $33.74 \pm 11.41$ lower when compared to T2 DM without ulcers $37.25 \pm 5.27$ (Sign. 0.264). The MCV value in T2DM with ulcers has a lower value compared to T2DM with ulcers $88.97 \pm 12.77$ $\mathrm{fl}$ while in T2DM it is $81.35 \pm 5.76 \mathrm{fl}$. $\mathrm{MCH}$ and $\mathrm{MCHC}$ values respectively in T2DM with ulcers 
$28.26 \pm 9.03 \mathrm{pg}$ and $32.11 \pm 9.84 \mathrm{~g} / \mathrm{dl}$ whereas in T2DM without ulcers $27.60 \pm 3.44 \& 33.66 \pm 2.69$ $\mathrm{g} / \mathrm{dl}$ respectively were not significantly different, namely 0.148 and 0.748 . The value of PLT with ulcers was $387.8 \pm 200.32 \times 10^{3} / \mu \mathrm{L}$ and in $\mathrm{T} 2 \mathrm{DM}$ without ulcers was $336.68 \pm 124.27 \times 10^{3} / \mu \mathrm{L}$ (Sign. 0.206) (Table 1).

Based on the analysis, RBC and $\mathrm{HGB}$ have significantly different values. The RBC and HGB values respectively in T2DM with ulcers were 3.77 $\pm 1.03 \times 100 / \mu \mathrm{L}$ and $10.14 \pm 2.33 \mathrm{~g} / \mathrm{dl}$ whereas in T2DM without Ulcers $4.56 \pm 0.55 \times 100 / \mu \mathrm{L}$ and $12.67 \pm 2.06 \mathrm{~g} / \mathrm{dl}$ (p: $0.012 \& 0.006)$. Anemia is often found in diabetic patients (Kothari \& Bokariya, 2012; Kizilgul et al., 2018). This study is supported by Wright (2014) study which stated that T2DM accompanied by ulcers was more likely to suffer from anemia. T2DM sufferers accompanied by ulcers are macrovascular complications that occur in about $15 \%$ of people with diabetes (Salman et al., 2017). $60-80 \%$ of sufferers will recover but 5-24\% will lead to amputation (Alexiadou \& Doupis, 2012).

The relationship between anemia and T2DM with ulcers is not yet well understood (Salman et al, 2017). However, several supporting factors have been identified. Among these factors are age (Fitria et al., 2017), history of amputation, insulin use, sex, distal neuropathy, foot deformities (Yazdanpanah et al., 2018). The number of reported events was also quite diverse. However, the majority stated that more than $50 \%$ of people with T2DM with ulcers had anemia (Kothari \& Bokariya, 2012; Salman et al., 2017). Anemia may also occur in other DM complications, namely kidney failure (Abate et al., 2013). Other research on the description of blood components showed that fasting blood glucose levels were isolated with hemoglobin and hematocrit (Christa, 2014). The incidence of anemia in diabetes allows for more severe complications including ischemic heart disease, hypertension, and kidney failure.

Anemia in DM Ulcers is associated with vascular complications such as nephropathy, retinopathy, and neuropathy which result in slow healing of the wound (Abate et al., 2013). Ulcer incidence reached $15 \%$ of total sufferers. Until now, amputation is the final path of complications (Salman et al., 2017). Anemia is reported to be a side effect of DM (Kothari \& Bokariya, 2012). Proteins from RBC membranes undergo oxidation through non-enzymatic glycosylation due to increased oxidative stress in diabetes and reduce levels of PCV, HB, RBC which can cause hemolysis and consequently become anemic (Mohammed et al., 2013).

\section{CONCLUSION}

The results of this study showed that red blood cell count (RBC) and Hemoglobin Count (HGB) differed significantly between T2DM with ulcers and T2DM without ulcers. Identification of HGB levels was highly recommended to get proper treatment in T2DM.

\section{ACKNOWLEDGMENTS}

Thank you to Rumah Luka for their availability as a place for sampling and respondent. Thank you also delivered to Qilmia, Siska, Dina, Livia and tri as Diabetes Mellitus Research team, Molecular Biology team, UMSIDA.

Table 1. Character and differences between T2DM ulcer and T2DM without ulcer

\begin{tabular}{|c|c|c|c|c|c|}
\hline Parameters & $\begin{array}{c}\text { means + SD } \\
\text { DM ulcer }\end{array}$ & $\begin{array}{c}\text { means + SD } \\
\text { without Ulcer }\end{array}$ & $\begin{array}{c}\text { Total means }+ \\
\text { SD }\end{array}$ & Statistical Test & $\begin{array}{c}\mathrm{P}- \\
\text { value }\end{array}$ \\
\hline $\mathrm{WBC}(/ \mu \mathrm{l})$ & $7210 \pm 3839.11$ & $8663.15 \pm 3668.81$ & $8162.06 \pm 3726.20$ & Independent T- test & 0.327 \\
\hline $\mathrm{RBC}(\times 100 / \mu \mathrm{L})$ & $3.77 \pm 1.03$ & $4.56 \pm 0.55$ & $4.28 \pm 0.82$ & Independent $\mathrm{T}$ - test & 0.012 \\
\hline HGB (g/dl) & $10.14 \pm 2.33$ & $12.67 \pm 2.06$ & $11.8 \pm 2.44$ & Independent T- test & 0.006 \\
\hline HCT & $33.74 \pm 11.41$ & $37.25 \pm 5.27$ & $36.04 \pm 7.91$ & Independent $\mathrm{T}$ - test & 0.264 \\
\hline $\operatorname{MCV}(\mathbf{f l})$ & $88.97 \pm 12.77$ & $81.35 \pm 5.76$ & $83.97 \pm 9.34$ & Mann-Whitney U & 0.141 \\
\hline MCH (pg) & $28.26 \pm 9.03$ & $27.60 \pm 3.44$ & $27.83 \pm 5.82$ & Mann-Whitney U & 0.148 \\
\hline $\mathrm{MCHC} \mathrm{g} / \mathrm{dl}$ & $32.11 \pm 9.84$ & $33.66 \pm 2.69$ & $33.12 \pm 6.03$ & Mann-Whitney U & 0.748 \\
\hline 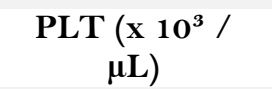 & $387.8 \pm 200.32$ & $336.68 \pm 124.27$ & $354.31 \pm 153.09$ & Mann-Whitney U & 0.206 \\
\hline Glucose (mg/dl & $239.2 \pm 752.52$ & $266.63 \pm 73.79$ & $257.17 \pm 74.23$ & & \\
\hline
\end{tabular}




\section{REFERENCES}

Abate, A., Birhan, W., \& Alemu, A. (2013). Association of anemia and renal function test among diabetes mellitus patients attending Fenote Selam Hospital, West Gojam, Northwest Ethiopia: A cross sectional study BMC Hematology. BMC Blood Disorders, 13(1), 1-12. doi: 10.1186/2052-1839-13-6.

Alexiadou, K., \& Doupis, J. (2012). Management of diabetic foot ulcers. Diabetes Therapy, 3(1), 115. doi: $10.1007 / \mathrm{s} 13300-012-0004-9$.

Aumiller, W. D., \& Dollahite, H. A. (2015) Pathogenesis and management of diabetic foot ulcers. Journal of the American Academy of Physician Assistants, 28(5), 28-34. doi: 10.1097/01.JAA.0000464276.44117.b1.

Biadgo, B. (2016). Hematological indices and their correlation with fasting blood glucose level and anthropometric measurements in type 2 diabetes mellitus patients in Gondar, Northwest Ethiopia. Diabetes, Metabolic Syndrome and Obesity: Targets and Therapy, 9(1), 91-99. doi: 10.2147/DMSO.S97563.

Christa, M.W.R. (2014). Hematological Parameters and Prediabetes and Diabetes in Adults from the General Population: A Cross-Sectional Study. Journal of Diabetes E Metabolism, 5(2), 335. doi: 10.4172/2155-6156.1000335.

Ekoe, J.M., Goldenberg, R., \& Katz, P. (2018). Clinical Practice Guidelines - Screening for Diabetes in Adults Diabetes Canada. Canadian Journal of Diabetes, 42, S109-S114. doi: 10.1016/j.jcjd.2017.10.013.

Fitria, E., Nur, A., Marissa, N., \& Ramadhan, N. (2017). Karakteristik Ulkus Diabetikum pada Penderita Diabetes Mellitus di RSUD dr. Zainal Abidin dan RSUD Meuraxa Banda Aceh. Buletin Penelitian Kesehatan, 45(3), 153 160. doi: 10.22435/bpk.v45i3.6818.153-160.

Hu, F.B. (2011). Globalization of diabetes: The role of diet, lifestyle, and genes. Diabetes Care, 34(6), 1249-1257. doi: 10.2337/dc11-0442.

Kizilgul, M., Sencar, E., Ucan, B., Beysel, S., Ozcelik, O., Ozbek, M., \& Cakal, E. (2018). Components of the Complete Blood Count in Type 2 Diabetes Mellitus with Inadequate Glycemic Control. Dicle Medical Journal, 45(2), 113-120. doi: 10.5798/dicletip.410811.

Kothari, R., \& Bokariya, P. (2012). A Comparative Study of Haematological Parameters in Type I mellitus Patients \& healthy Young Adolescents. International Journal of Biological and Medical Research, 3(4), 2429-2432. Retrieved from https://pdfs.semanticscholar.org/49bc/c96acd 6efea6a556750b8c8273e10b9108ff.pdf.

Lathifah, N.L. (2017). Hubungan durasi penyakit dan kadar gula darah dengan keluhan subyektif penderita diabetes mellitus. Jurnal Berkala Epidemiologi, 5(2) 231-239. doi: 10.20473/jbe.v5i2.2017.231-239.

Loviana, R.R., Rudy, A., \& Zulkarnain, E. (2015). Artikel Penelitian Faktor Risiko Terjadinya Ulkus Diabetikum pada Pasien Diabetes Mellitus yang Dirawat Jalan dan Inap di RSUP Dr. M. Djamil dan RSI Ibnu Sina Padang. Jurnal Kesehatan Andalas, 4(1), 243-248. doi: https://doi.org/10.25077/jka.v4i1.229

Mirtha, L.T., Ariono, M., \& Putra, S.M. (2018). The Effect of Foot Exercise on Diabetic Patients with Foot Ulcer: An Evidence-Based Case Report. Diabetes \& Metabolic Disorders, 5(1),1-5. Diakases dari https://doi.org/10.24966/dmd-201x/ 100026

Mohammed, R.K., Ibrahim, S., Atawodi, S.E., Eze, E.D., Suleiman, J.B., Ugwu, M.N., \& Malgwi, I.S. (2013). Anti-diabetic and Haematological Effects of n-butanol fraction of Alchornea cordifolia Leaf Extract in Streptozotocininduced Diabetic Wistar Rats. Scientific Journal of Biological Sciences, 2(3), 45-53. doi: 10.13140/RG.2.2.35936.17921

Ramkisson, S., Pillay, B. J., \& Sibanda, W. (2017). Social support and coping in adults with type 2 diabetes. African Journal of Primary Health Care and Family Medicine, 9(1), 8. Retrieved from https://phcfm.org/index.php/phcfm/article/vi ew/1405/2160.

Salman, I. N., Wadood, S. A., \& Abualkasem, B. A. (2017). Low Hemoglobin Levels in Infected Diabetic Foot Ulcer. IOSR Journal of Pharmacy and Biological Sciences, 12(01), 05-09. https://doi.org/10.9790/3008-1201040509

Suneja, S., Christian, Y., \& Chandra, N. C. (2018) Milieu of Diabetes in the 2nd Decade of $21 \mathrm{st}$ Century. Journal of Diabetes \& Metabolism, 09(09), 1-14. doi: 10.4172/2155-6156.1000804.

Thomas, M., Tsalamandris, C., MacIsaac, R., \& Jerums, G. (2005). Anaemia in Diabetes: An Emerging Complication of Microvascular Disease. Current Diabetes Reviews, 1(1), 107126.https://doi.org/10.2174/15733990529525 87

Tsaih, S.W., Holl, K., Jia, S., Kaldunski, M., Tschannen, M., He, H., Woods, L. C. S. (2014). Identification of a Novel Gene for Diabetic Traits in Rats, Mice, and Humans. Genetics, 198(1),17-29.

https://doi.org/10.1534/genetics.114.16298

WHO. (2004). Estimates for the year 2000 and projections for 2030. World Health, 27(5), 1047-1053.

Wright, J.A., Oddy, M.J., \& Richards, T. (2014). Presence and characterisation of anaemia in diabetic foot ulceration. Anemia, 2014, pp. 1-8. doi: $10.1155 / 2014 / 104214$. 
Yazdanpanah, L., Shahbazian, H., Nazari, I., Arti, H. R., Ahmadi, F., Mohammadianinejad, S. E., \& Hesam, S. (2018). Incidence and risk factors of diabetic foot ulcer: A population-based diabetic foot cohort (ADFC study)-two-year follow-up study. International Journal of Endocrinology,

2018.
Yuhelma., Hasneli, I.Y., \& Annis, N.F. (2015) Identifikasi dan Analisis Komplikasi Makrovaskuler dan Mikrovaskuler pada Pasien Diabetes Mellitus. Journal Online Mahasiswa, 2(1), 569-579. Diakses dari https://jom.unri.ac.id/index.php/JOMPSIK/a rticle/view/8343/8012. 